\title{
Effect of Treatment with Enalapril, Frusemide and a Low-sodium Diet on Dogs with Mitral Regurgitation
}

\author{
E. Ynaraja ${ }^{1}$, A. Caro ${ }^{1}$, J.A. Montoya ${ }^{2 *}$
}

${ }^{1}$ Internal Medicine

Faculty of Veterinary Science of Madrid, Spain

${ }^{2}$ Internal Medicine

Faculty of Veterinary Science of Las Palmas de Gran Canaria University, 35416-Arucas, Las Palmas, Spain

(Received December 27. 2001; accepted September 7, 2002)

\begin{abstract}
Ynaraja, E., Caro, A. and Montoya, J.A. 2002. Effect of treatment with enalapril, frusemide and a low-sodium diet on dogs with mitral regurgitation. J. Appl. Anim. Res., 22: 219-224.

Thirty-five dogs with congestive heart failure due to chronic mitral valve disease were treated with frusemide $(1 \mathrm{mg} / \mathrm{kg}$ bid), enalapril $(0.4 \mathrm{mg} / \mathrm{kg}$ bid) and a low-sodium diet to evaluated the effects produced by combination of these drugs and to ascertain the possible negative effects following the use of these drugs. The treatment was safe, effective and well tolerated. No major side effects and no significant changes in haematological and biochemical variables were observed.
\end{abstract}

Keywords: Dog, mitral disease, frusemide, enalapril, low-sodium diet, cardiology, CHF.

\section{Introduction}

Congestive heart failure (CHF), due to chronic mitral valve endocardiosis, is one of the most commonly encountered conditions

* For correspondence.

J. Appl. Anim. Res. 0971-2119/2002/\$5.00 (C GSP, India. 
in small animal practice and causes a considerable reduction in life expectancy and life quality (Buchanan, 1999; Kittleson, 2000). Current therapy, based on a combination of diuretics and vasodilators of the angiotensin converting enzyme inhibitors (ACEI) group and a low-sodium diet has been shown to be effective in controlling CHF in dogs (Ettinger et al., 1998; Kittleson, 2000).

Frusemide, a potent loop diuretic, has been used in dogs with $\mathrm{CHF}$ and it is the only registered drug by FDA (Kittleson, 2000). Enalapril, a second-generation ACEI suitable for use in small animals, has several advantages to captopril. Enalapril is reported to be well tolerated. After absorption, it is hydrolysed to the active metabolite, enalapril maleate. Some studies have shown beneficial effects of enalapril after a single daily dose or bid dose (Biller et al., 1998; Kittleson, 2000). Finally, before starting combined therapy in any patient and especially in geriatric patients with CHF, it is important to consider the possible appearance of problems stemming from drug interactions. This article reports the clinical response and effect on blood and urine electrolyte variable of combined short-term treatment with frusemide, enalapril and low sodium diet in dogs with stage II CHF.

\section{Materials and Methods}

Study included 35 male dogs $(6-12 \mathrm{yr}, 5-15 \mathrm{~kg})$ with stage II CHF (secondary to mitral endocardiosis) classified as per International Small Animal Cardiac Health Council (ISACHC). The animals had no previous treatment or recurrent diseases. All dogs were pets from urban households, which received moderate exercise and had been appropriately vaccinated and dewormed.

Patients were attended in the Cardiology Service of the Faculty of Veterinary Science of Madrid. A clinical history, a complete physical examination and electrocardiographic, radiological and echocardiographic studies were made. Haematological tests (WBC, RBC, haemoglobin, haematocrit, platelets) and serum biochemical analyses (total proteins, albumin, urea, creatinine, glucose, gamma glutamyltransferase, alanine aminotransferase, alkaline phosphatase, bilirubin, sodium, potassium, phosphorus, chloride, 
calcium) and urinary fractional excretion (FE) of electrolytes and urinalysis were performed.

Medical treatment involved the administration of enalapril (Renitec ${ }^{\circledR}$ ) $0.4 \mathrm{mg} / \mathrm{kg}$, bid and frusemide (Seguril ${ }^{\circledR}$ ) $1 \mathrm{mg} / \mathrm{kg}$, bid given orally over the course of 1 month. The diet was restricted to lowsodium dog chow (Prescription k/d Hill's $\mathrm{s}^{\circledast}$ ). Changeover from the usual diet to the low-sodium diet was effected over 1 week. All tests were repeated weekly and results were assessed 4 weeks after starting full treatment (5 weeks with the low-sodium diet and 4 weeks with medication).

The statistical study was carried out using the program LOTUS 1-2-3, 2.2 (Lotus Corp ${ }^{\boxplus}$ ). For each variable and class means, statistical significance were calculated at $\mathrm{p}<0.05$.

\section{Results and Discussion}

Throughout the study, treatment was associated with reduction in signs of CHF and significant clinical responses. After treatment all owners reported a notable improvement in their dogs in respect to clinical signs. There were no side effects requiring suspension of medication or withdrawal of any patient from the study and no clinical signs of renal or liver failure were recorded. The most important side effect observed in our patients was a polyuria/ polydipsia during the first and second day after starting the treatment. We did not find any significant secondary effects stemming from the administration of the drug with regard to hypotension or cardiac arrhythmias. This was in agreement with earlier report (Martinez-Alcaine et al., 2001).

The reduced prevalence of despond and cough was accompanied by increased exercise tolerance. No after treatment syncope was observed. Ascites observed in dogs disappeared after treatment. Appetite returned to normal after treatment in all patients initially presenting inappetence.

Pulmonary oedema disappeared after treatment in all the 8 dogs suffering from this problem. Several studies carried out with ACEI in veterinary medicine demonstrate the capacity of these drugs 
to improve, even reverse, lung oedema because of their venous vasodilator and diuretic effects (Kittleson, 2000; Martinez-Alcaine et al., 2001). Similarly 14 dogs had vena cava distension before treatment and only 6 after treatment. However no significant changes occurred in cardiomegaly and cardiac base-apex index during treatment.

We noticed a statistically significant decrease in heart rate and a not significant decrease in the incidence and/or severity of cardiac arrhythmias after treatment. The number of animals showing normal sinus rhythm on ECG increased (40\% before treatment and $63 \%$ after treatment). Treatment induced no arrhythmia in the patients, which indicates perfect tolerance to the drugs and the nonexistence of drug interaction (Vargo et al., 1995; Kittleson, 2000).

Anatomical changes in the atrioventricular valves in the $80 \%$ of patients observed before treatment, disappeared after treatment.

Haematological and blood biochemical values, before and after treatment, were within reference ranges for species, age, breed and sex. The serum values of sodium, calcium, phosphorus and chloride remained unchanged before and after the treatment and were within normal limits. Serum potassium level, though within normal range decreased $(p<0.01)$ after treatment (Table 1). No ECG changes due

Table 1

Serum electrolyte values $(\mathrm{mmol} / \mathrm{l})$ (mean $\pm \mathrm{SD}$ ) in dogs treated for CHF using frusemide, enalapril and a low sodium diet

\begin{tabular}{lrrrr}
\hline $\begin{array}{l}\text { Serum } \\
\text { electrolyte }\end{array}$ & $\begin{array}{c}\text { Before } \\
\text { treatment } \\
\mathrm{n}=35\end{array}$ & $\begin{array}{c}\text { After } \\
\text { treatment } \\
\mathrm{n}=35\end{array}$ & $\begin{array}{c}\text { Reference } \\
\text { range* }\end{array}$ & $\begin{array}{c}\text { Statistical } \\
\text { significance }\end{array}$ \\
\hline Sodium & $146 \pm 3.15$ & $141 \pm 2.62$ & $139-164$ & $\mathrm{P}>0.05$ \\
Potassium & $4.18 \pm 0.29$ & $3.91 \pm 0.23$ & $4.4-6.1$ & $\mathrm{P}<0.01$ \\
Chloride & $113 \pm 3.12$ & $108 \pm 3.09$ & $100-118$ & $\mathrm{P}>0.05$ \\
Calcium & $2.79 \pm 0.65$ & $2.7 \pm 0.69$ & $2.3-2.9$ & $\mathrm{P}>0.05$ \\
Phosphorus & $1.71 \pm 0.80$ & $1.58 \pm 0.59$ & $1.0-1.9$ & $\mathrm{P}>0.50$ \\
\hline
\end{tabular}

* Clinical pathology laboratory service. Veterinary Science of Madrid, Spain. 
to abnormal level of potassium were observed. This would be due to the kaliuretic effect of frusemide. On the other hand this result is different from the result obtained with the administration of quinapril, bumetanide and a low-sodium diet in a similar group of dogs (Martínez-Alcaine et al., 2001).

Urinary FE sodium and chloride values remained within normal range pre- and post-treatment (Table 2). Phosphorus value, though below normal pre-treatment and within normal posttreatment did not differ significantly. Only urinary FE calcium and potassium values increased significantly post treatment.

Table 2

Urinary FE of electrolytes (\%) (mean \pm SD) in dogs treated for CHF using frusemide, enalapril and a low sodium diet

\begin{tabular}{lcrrr}
\hline $\begin{array}{l}\text { Serum } \\
\text { electrolyte }\end{array}$ & $\begin{array}{c}\text { Before } \\
\text { treatment } \\
\mathrm{n}=35\end{array}$ & $\begin{array}{c}\text { After } \\
\text { treatment } \\
\mathrm{n}=35\end{array}$ & $\begin{array}{c}\text { Reference } \\
\text { range }^{*}\end{array}$ & $\begin{array}{c}\text { Statistical } \\
\text { significance }\end{array}$ \\
\hline Sodium & $0.05 \pm 0.06$ & $0.21 \pm 0.24$ & $0.06-0.64$ & $\mathrm{P}>0.05$ \\
Potassium & $0.51 \pm 2.1$ & $9.11 \pm 10.28$ & $0.3-20$ & $\mathrm{P}<0.05$ \\
Calcium & $4.3 \pm 3.21$ & $12.3 \pm 8.92$ & $2.9-8.1$ & $\mathrm{P}<0.05$ \\
Phosphorus & $5.2 \pm 5.28$ & $12.4 \pm 10.32$ & $5.1-21.3$ & $\mathrm{P}>0.05$ \\
Chloride & $0.31 \pm 0.48$ & $0.28 \pm 0.33$ & $0.1-0.7$ & $\mathrm{P}>0.05$ \\
\hline
\end{tabular}

${ }^{*}$ Clinical pathology laboratory service, Veterinary Science of Madrid, Spain.

This study confirms that the combined treatment administered for controlling dogs CHF due to mitral endocardiosis is well accepted and is also safe and effective in controlling clinical signs.

\section{References}

Biller, B., Horauf, A. and Draft, W. 1998. Treatment of mitral valve insufficiency in dogs with the ACE inhibitor enalapril. A clinical progress study. Tierarztliche Praxis., 26: 21-30.

Buchanan, J.W. 1999. Prevalence of Cardiovascular Disorders. In: Textbook of Canine and Feline Cardiology: Principles and Clinical Practice. 2nd edition. P.R. Fox, D. Sisson, and N.S. Moïse(eds.). W.B. Saunders Company. Philadelphia, Pennsylvania. pp. 457-470. 
Ettinger, S.J., Benitz, A.M., Ericsson, G.F., Cifelli, S., Jernigan, A.D., Longhofer, S.L., Trimboli, W. and Hanson, P.D. 1998. Effects of enalapril maleate on survival of dogs with naturally acquired heart failure. The Long. Term Investigation of Veterinary Enalapril (LIVE) Study Group. J. Amer. Vet. Med. Assoc., 213: 1573-1577.

Kittleson, M.D. 2000. Therapy of Heart Failure. In: Textbook of Veterinary Internal Medicine. 5th edition. S.J. Ettinger and E.C. Feldman (eds.). W.B. Saunders Company, Philadelphia, Pennsylvania. pp. 713-737.

Martínez-Alcaine, M.A., Ynaraja, E., Corbera, J.A. and Montoya, J.A. 2001. Effect of short-term treatment with bumetanide, quinapril and low-sodium diet on dogs with moderate congestive heart failure. Aust. Vet. J., 79: 102-105.

Vargo D., Kramer, W.G. and Black, P.K. 1995. Bioavailability, pharmacokinetics, and pharmacodynamics of torsemide and frusemide in patients with congestive heart failure. Clin. Pharmacol. Ther., 57: 601-609.

इ.याराजा, ए.कैरो, जे.ए.मोन्टोया। मिट्रल प्रत्यावहन पीड़ित कुत्तों पर इनालैप्रिल, फ़ुसेमाइड और अल्प सोडियम युक्त आहार उपचार का प्रभाव।

चिरकाली मिट्रल कपाट व्याधि के कारण रक्ताधिक्य हृदयाघात से पीड़ित 35 कुत्तों का उपचार फ़ुसेमाइड, इनालैप्रित और अल्प सोडियम युक्त आहार पर इनके संयोजन के प्रभाव का तथा उसके बाद के संभव नकारात्मक प्रभाव का मूल्यांकन किया गया। उपचार सुरक्षित प्रभावी और बहुत ही सह्य था। इससे कोई खास अन्य दुस्प्रभाव नहीं पड़ा तथा रूधिर के ऊत्तकों और रसायनिक घटकों पर सार्थक प्रभाव नहीं पड़ा। 